were issued during the year, and the British Section concentrated its attention on an attempt to lay the foundations of an area organization throughout Great Britain. The report of the New Commonwealth Institute for the same period refers to the initiation of a Monthly Information Bulletin and to the formation of four special research committees, dealing respectively with legal, military, political and psychological questions. The Legal Research Committee adopted as a basis for its discussions Prof. Strupp's study and proposals for an International Peace Convention, and considerable progress has been made in the establishment of an adequate research library on problems of peaceful change and collective security.

\section{Journal of Pomology and Horticultural Science}

IN view of the increasing number of contributions to the Journal of Pomology and Horticultural Science received from overseas, it is felt that the scope of the journal, hitherto the official organ of the Long Ashton and East Malling Research Stations, should be extended to provide a medium for the publication of the results of horticultural research of wider interest. The editors have accordingly obtained the services of the following as associate editors: M. B. Davis, Central Experiment Farm, Ottawa, Canada; Dr. C. Barnard, Division of Plant Industry, Council for Scientific and Industrial Research, Canberra City, F.C.T., Australia; L. W. Tiller, Department of Scientific and Industrial Research, Wellington C.1, New Zealand; Prof. E. E. Cheesman, Imperial College of Tropical Agriculture, Trinidad. Intending contributors overseas are asked to submit their papers in the first instance to the associate editor in their respective countries.

\section{Agricultural Research}

THE annual volume for 1937 of the Journal of the Royal Agricultural Society of England has now been published and includes as in recent years the "Farmer's Guide to Agricultural Research". The latter has been a feature of the Society's publications for the past twelve years, and consists of a number of valuable summaries of recent research work in the leading branches of agriculture, each section being prepared by an acknowledged expert on the subject. The various sections and the authors responsible for them are the same as in the previous issue. Space does not allow of reference to all the many interesting articles in this number of the journal, but mention may be made of the account of two centuries of Cheshire cheese farming, which gives a vivid and often humorous picture of agricultural life in England during the period under review. The Leckford Estate, Ltd., forms this year's subject in the series of notable farming enterprises.

\section{Polar Exhibition}

A PRELIMINARy circular has been issued of the projected International Exhibition of Polar Explora. tion which is to be held at Bergen from May until
September, 1940, under the patronage of the King of Norway and the presidency of the Prime Minister, the Ministers of Foreign Affairs and Commerce and the chairman of the council of the city of Bergen. The aim is to present a general survey of exploration, natural conditions and inhabitants and resources in arctic and antarctic regions. Polar regions of all States are to be included. Exhibits will consist of charts, models of vessels and aeroplanes, instruments, equipment, diaries, photographs and paintings. Whaling, sealing, trapping and tourist traffic will also be represented. Buildings are to be erected for the exhibition, which will be held contemporaneously with a national exhibition of arts, crafts, fisheries and communications. The offices of the Polar Exhibition are Telegrafbygningen, Bergen, Norway.

\section{National Baby Week Council and Physical Fitness}

The National Baby Week Council holds, and rightly so, that "physical fitness begins in the maternity and child welfare centre", which will be its slogan for this year. The centres cater for the well-being of the expectant mother, the nursing mother, the infant and child up to five years of age. A good start towards physical fitness can, and should, be given in those centres. The Council emphasizes that physical fitness cannot be obtained by physical exercise alone, and that nutrition, better housing and other reforms also bear a close relation to the whole problem. The Council will gladly advise representatives of organized bodies, or any individual requiring advice. Correspondence should be addressed to the Secretary, National Baby Week Council, 117 Piccadilly, London, W.1.

\section{British Health Resorts Association}

A NEW edition of the official handbook of the British Health Resorts Association has recently been issued (British Health Resorts-Spa, Seaside, Inland ; including those of the British Dominions and Colonies. London: J. and A. Churchill, Ltd. 2s. 6d. net). The publication gives a brief, authoritative and impartial account of British health resorts, as contrasted with the purely holiday resort. The book is supervised by a medical advisory committee, contains a chapter on "Climate, Health and the British Resort", and gives general information which will enable medical men and their patients to make their choice of a suitable place.

\section{National College of Physical Training}

A sITE of more than two hundred acres on high ground at Merstham, Surrey, has been selected for the National College of Physical Training, which is to be erected under the Physical Training and Recrea. tion Act for the purpose of training teachers and leaders. The land is protected on all sides from building encroachment, not only by natural features, but also, through the foresight of the local authorities, by town planning schemes, while close by are areas acquired in connexion with the 'Green Belt'. 